Original Article

\title{
EFFECTS OF AQUEOUS STEM BARK EXTRACT OF XYLOPIA AETHIOPICA ON THE REPRODUCTIVE FUNCTIONS OF MALE RATS
}

\section{CYPRIEN MAGLOIRE HAMBE ${ }^{1}$, MARIE NGAHA NJILA ${ }^{1}$, HUBERT KENMOGNE ${ }^{1}$, BRICE LANDRY KOLOKOㄹ, DIEUDONNE MASSOMA LEMBE*1}

\author{
${ }^{1}$ Department of Animal Sciences, Faculty of Science, University of Douala, 24157 Douala, Cameroon \\ Email: pmasso@yahoo.fr
}

Received: 16 Aug 2017 Revised and Accepted: 22 Nov 2017

\begin{abstract}
Objective: The sexual stimulatory effect of aqueous stem bark extract of Xylopia aethiopica which is commonly used traditionally for the treatment of fertility-related problems in males is reported in this work.

Methods: The present study investigated the effect of $14 \mathrm{~d}$ oral administration of $1 \mathrm{ml} / \mathrm{kg}$ distilled water (control), $100,200 \mathrm{and} 300 \mathrm{mg} / \mathrm{kg}$ of body weight of the stem bark extract on some fertility parameters of the Swiss male rats. So, all the target organs (testis, epididymis, vas deferens, seminal vesicle and prostate) were weighed. The sperm motility and sperm count in testis, epididymis and vas deferens were determined. Serum and tissue protein, as well as cholesterol, were evaluated. The serum testosterone level was also assessed.

Results: The extract did not produced significant change in the mobility of sperm, the sperm count in vas deferens, the relative weight of body and accessory organs at all doses. The daily sperm production (DSP) and the weight of prostate significantly increased at a dose of $100 \mathrm{mg} / \mathrm{kg}$ (p<0.01) while the sperm count in cauda epididymis increased at a dose of $200 \mathrm{mg} / \mathrm{kg}$. The testicular and serum cholesterol significantly increased ( $\mathrm{p}<0.001)$ at the dose of $100 \mathrm{mg} / \mathrm{kg}$ whereas the testicular and serum proteins increased $(\mathrm{p}<0.001)$ at the dose of $200 \mathrm{mg} / \mathrm{kg}$. The serum testosterone level increased following $14 \mathrm{~d}$ of treatment $(\mathrm{p}<0.01)$ at the dose of $100 \mathrm{mg} / \mathrm{kg}$.
\end{abstract}

Conclusion: The results suggest that Xylopia aethiopica may have the potentials of being developed into a male fertility enhancing drug.

Keywords: Spermatogenesis, Xylopia aethiopica, Testosterone level, Fertility

(C) 2018 The Authors. Published by Innovare Academic Sciences Pvt Ltd. This is an open access article under the CC BY license (http://creativecommons.org/licenses/by/4.0/) DOI: http://dx.doi.org/10.22159/ijpps.2018v10i1.22038

\section{INTRODUCTION}

Since time immemorial, all civilizations have always relied on plants and their products in the field of treatment and cure of diseases. Although the last centuries, the development of scientific research has provided many facilities in the domains of healthcare, infertility remains one of the problems of human society in which $40 \%$ of these problems are due to male factor [1].

There are many herbal drugs that have been used traditionally to treat sperm abnormalities, erectile and ejaculatory dysfunction [24]. Xylopia aethiopica (Annonaceae) is a tree over $20 \mathrm{~m}$ in height and $60-75 \mathrm{~cm}$ in diameter which grows in forested areas and especially along the rivers in arid zones [5]. In Cameroon, Xylopia aethiopica has been identified in the South in the locality of Ebondi and locally known as "Iting". Many therapeutic effects such as the treatment of a cough, bronchitis, rheumatism, dysentery and infertility are already been found when using the aerial parts of Xylopia aethiopica [6].

Previous phytochemical investigations of Xylopia aethiopica yielded alkaloids, saponins, tannins, terpenes [7], flavonoids and glycosides [8]. The increasing incidence of male infertility is always necessitating scientific research into plants with fertility enhancing potentials. This work is intended to study the effect of Xylopia aethiopica on sperm cells formation and androgen level of male rats

\section{MATERIALS AND METHODS}

Chemicals and reagents

Reagents used were procured from Polypharmacy (Douala, Cameroon). The standard drugs were purchased from SIGMAALDRICH Chemical Co (St. Louis, MO, USA) and DIAGNOSTIC Products Co (Los Angeles, CA, USA). All other reagents were of analytical grade.

\section{Plant material}

The fresh stem bark of Xylopia aethiopica was collected during the month of May in the locality of to Ebondi of the southern region of Cameroon. The botanical identification of the plant was made in the national Herbarium of Cameroon at Yaoundé by GHOGUE Jean Paul, Senior Researcher/Environmentalist in comparison to the sample $\mathrm{N}$ 'JJ 7931 (De Wilde).

\section{Extract preparation}

The stem bark of Xylopia aethiopica was cut into small species and air-dried in the shade away from the dust and then crushed. The extraction is done in accordance with the requirements of traditional physiscians. A $500 \mathrm{~g}$ of the powdered stem bark was suspended in $6 \mathrm{l}$ of distilled water, heated and boiled under reflux for $45 \mathrm{~min}$. After filtration by the Whatman $\mathrm{N}^{\circ} 3$ filter paper, the obtained decoction was stored at- $20^{\circ} \mathrm{C}$ for lyophilisation. The crude yield of the lyophilised material was approximately $29.1 \mathrm{~g}$ (5.82\%.). The lyophilised extract was further diluted to obtain different concentrations in $1 \mathrm{ml}$. Obtained solutions were kept at $4{ }^{\circ} \mathrm{C}$ until further used.

\section{Screening of the plant}

According to the Guidelines for the appropriate use of herbal medicines [9] (WHO, 1998), Different oral doses up to $2 \mathrm{~g} / \mathrm{kg}$ body weight (BW) of an extract of Xylopia aethiopica was given to different groups of mice and observe $48 \mathrm{~h}$ later to determine any sign of toxicity. No toxic effect was observed during the period of the test (data not shown).

\section{Animals}

Our study was conducted with 24 adult male rats from the Wistar strain Albino weighing between 150-250 g obtained from the vivarium at the University of Douala. The animals were housed six 
animals per cage in a room with controlled temperature (temperature $\left.24-28{ }^{\circ} \mathrm{C}\right)$ and lighting (12 h light-dark cycles). The Ethics Committee of the University of Douala in accordance with the internationally accepted principles for laboratory use and care of European Community (EEC directive of 1986; 86/609/EEC) approved the protocol for these experiments. In an attempt to further validate scientifically the traditional claims, the rats were divided into the following 4 groups (6 per group) and orally treated with $1 \mathrm{ml} / \mathrm{kg}$ distilled water (control), 100, 200 and $300 \mathrm{mg} / \mathrm{kg}$ body weight (BW) per day of Xylopia aethiopica for $14 \mathrm{~d}$. The Xylopia aethiopica extract diluted in water or vehicle (water) was administered by gavages. One day after the last treatment, the animals were sacrificed and a blood sample was collected for testosterone assay and biochemical analysis. Testis, seminal vesicles, epididymis and ventral prostate were removed and cleared of attached fat and connective tissue and weighed. The testis, vas deferens and epididymis were used for biochemical analysis, sperm count and motility.

\section{Sperm count}

\section{Sperm count in epididymis}

Homogenization-resistant epididymal sperm from non-perfused rats were counted as described previously [10]. Sperm counts were measured in caput/corpus and cauda of the left epididymis. Homogenization was performed in $5 \mathrm{ml}$ of saline $(\mathrm{NaCl} 0.9 \%)$. Homogenates were kept refrigerated at $4{ }^{\circ} \mathrm{C}$ for $24 \mathrm{~h}$ to allow sperm to be released from the walls. Then $1 \mathrm{ml}$ of the refrigerated homogenate was added to $7 \mathrm{ml}$ (dilution 1/8) of eosin (0.2\%) and a sample was placed in a Neubauer chamber. Head sperms were counted in 25 squares for 4 times. The average sperm count of each rat was multiplied by 0.08 (sperm $\times 10^{6} / \mathrm{ml}$ ) and then by $5 \mathrm{ml}$ (sperm $\times 10^{6}$ per caput/corpus or cauda). Data are referred as sperm per caput/corpus or cauda epididymis.

\section{Sperm count in vas deferens}

The vas deferens was cut in two parts corresponding to the large and thin one. Each part was homogenized with $1 \mathrm{ml}$ of saline $(0.9 \%)$. An aliquot was diluted with two parts of eosin $(0.2 \%)$. Homogenization resistant sperm heads were counted in the 25 squares of the Neubauer chamber. Four chambers were measured in each sample, and they were averaged. Results from the large and the thin part were multiplied by 0.03 and defined as sperm $\times 10^{6}$ per part of vas deferens. Data were expressed as the total amount of sperms in vas deferens (sperm count in the large and the thin part of vas deferens).

\section{Daily sperm production}

The capsule of the left testis was removed and the parenchyma was homogenized in $10 \mathrm{ml}$ of $0.9 \%$ saline $/ 0.05 \%$ Triton X-100 (v/v) solution for $1 \mathrm{~min}$ by a homogenizer [11] and then diluted into $1 / 10$ with saline. The number of homogenization-resistant elongated spermatid nuclei per testis was determined with a hemocytometer. Counts for 4 hemocytometer chambers were averaged. The daily sperm production (DSP) were determined by the division of the elongated spermatid count per testis and spermatids per gram of testis by 6.3 , which represents, the duration of steps 17 to 19 spermatids in the seminiferous epithelial cycle for rats [12]. The epididymal sperm transit rate was calculated by dividing the cauda epididymal sperm number by the DSP [13].

\section{Sperm motility determination}

The cauda epididymis was separated and minced using a pair of small scissors, to release the sperm into $10 \mathrm{ml}$ of warmed physiological saline. The sperm suspension was placed in an incubator at $37^{\circ} \mathrm{C}$ for $10 \mathrm{~min}$ prior to total motility and progressive motility assessment. The aliquot of the sperm suspension was then placed on Makler counting chamber and motile sperm was counted under a light microscope (BX41, OLYMPUS). Nine microscopic fields were observed per sample and averaged. Progressive and total sperm motility was expressed as a percent of motile sperm of the total sperm count.

\section{Biochemical analyses}

Biochemical analyses were determined using commercial kits. Total protein levels were determined in the serum and sexual organ (testis and epididymis) using colourimetric methods described by Gornal et al. [14] and Bradford [15] respectively. The cholesterol levels in the tests were determined using the colourimetric method described by Forbes [16]. Serum testosterone levels were determined by ELISA method.

\section{Statistical analysis}

All statistical analysis was conducted using the STATGRAPHICS PLUS SOFTWARE (version 5.0). Results were expressed as mean \pm SEM (standard error of the mean). Differences between groups were assessed by one-way analysis of variance (ANOVA). When the differences were significant, the classification of Tukey test was used to locate the differences between the averages. When variance was not homogeneous a non-parametric analysis was performed. A value of $\mathrm{P}<0.05$ was considered as statistically significant.

\section{RESULTS}

Effects of aqueous extract of Xylopia aethiopica on body and accessory organs weight

After $14 \mathrm{~d}$ of treatment, no significant change was observed on the body weight of all treated group as compared with control group. However, the relative weight of prostate significantly increased $(\mathrm{P}<0.01)$ at the single dose $100 \mathrm{mg} / \mathrm{kg}$ as compared to the control.

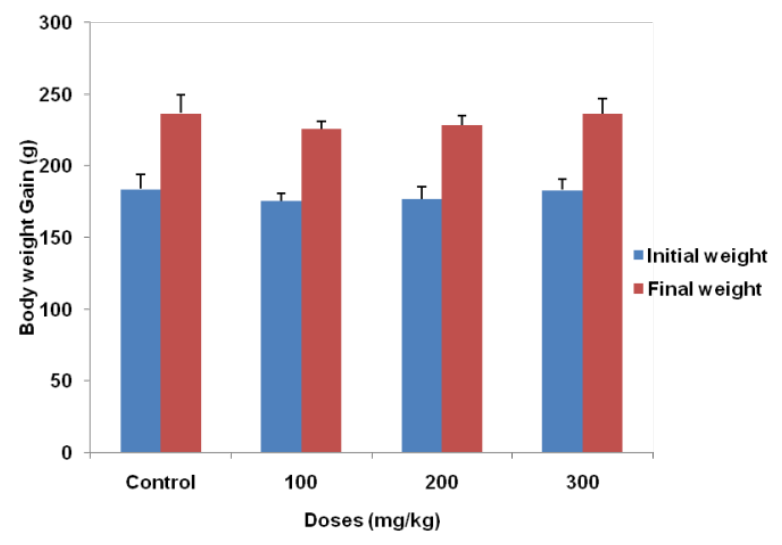

Fig. 1: Effects of aqueous extract of Xylopiaa ethiopica on relative body weight, value are mean $\pm S E M ; n=6$

Table 1: Effects of aqueous extract of Xylopiaa ethiopica on relative organs weight

\begin{tabular}{llll}
\hline Parameters & Doses $(\mathbf{m g} / \mathbf{k g})$ & $\mathbf{2 0 0}$ \\
\cline { 2 - 4 } & control & $\mathbf{1 0 0}$ & $0.590 \pm 0.030$ \\
\hline Testis & $0.570 \pm 0.020$ & $0.620 \pm 0.030$ & $0.164 \pm 0.020$ \\
Epididymis & $0.171 \pm 0.008$ & $0.172 \pm 0.010$ & $0.026 \pm 0.002$ \\
Vas deferens & $0.024 \pm 0.002$ & $0.024 \pm 0.003$ & $0.280 \pm 0.040$ \\
Seminal vesicle & $0.280 \pm 0.050$ & $0.390 \pm 0.008$ & $0.155 \pm 0.009$ \\
Prostate & $0.106 \pm 0.015$ & $0.155 \pm 0.080^{* *}$ & $0.030 \pm 0.003$ \\
\hline
\end{tabular}

Value are mean $\pm S E M ; n=6$; value is statistically significant at $\mathrm{P}<0.01$ level of significance. ${ }^{* *}$-compared with control $\mathrm{P}<0.01$ 
Effect of aqueous extract of Xylopia aethiopica on sperm count and sperm motility

After $14 \mathrm{~d}$ of treatment, aqueous extract of Xylopia aethiopica significantly affected the daily sperm production (DSP) in testis at dose of $100 \mathrm{mg} / \mathrm{kg}$ whereas there were no significant changes concerning the sperm motility in epididymis at all doses. At the other hand, we noticed a significant increase in sperm count $(\mathrm{P}<0.05)$ and transit $(\mathrm{P}<0.01)$ in epididymis at the dose of 200 $\mathrm{mg} / \mathrm{kg}$ (table 2). Regression analysis showed a significant correlation $\left(\mathrm{r}^{2}=0.98\right)$ between the sperm transit in the cauda epididymis and epididymal proteins.

Table 2: Effect of aqueous extract of Xylopia aethiopica on sperm count $\left(\mathrm{x}^{1} 0^{6}\right)$ and sperm motility (\%)

\begin{tabular}{llll}
\hline Parameters & Doses (mg/kg) & & \\
\cline { 2 - 4 } & Control & $\mathbf{1 0 0}$ & $\mathbf{2 0 0}$ \\
\hline DSP & $19.40 \pm 1.58$ & $22.78 \pm 0.71^{* *}$ & $15.52 \pm 0.76$ \\
DSP/weight testis & $14.67 \pm 1.53$ & $16.33 \pm 0.92$ & $11.71 \pm 0.86$ \\
Epididymis & $101.13 \pm 16.89$ & $102.13 \pm 21.13$ & $126.88 \pm 18.31^{*}$ \\
Vas deferens & $0.53 \pm 0.10$ & $0.57 \pm 0.10$ & $13.60 \pm 1.63$ \\
Sperm transit & $3.07 \pm 0.55$ & $3.59 \pm 0.15$ & $0.62 \pm 0.13$ \\
Sperm motility & $56.71 \pm 0.84$ & $63.75 \pm 4.76$ & $.719 \pm 0.32 * *$ \\
\hline
\end{tabular}

Value are mean \pm SEM; $\mathrm{n}=6$; values are statistically significant at $\mathrm{P}<0.05$ and $\mathrm{P}<0.01$ level of significance. ${ }^{*}$-compared with control $\mathrm{P}<0.05,{ }^{* *}$ compared with control $\mathrm{P}<0.01$

\section{Biochemical profile in the serum and sexual organs}

Administration of aqueous extract of Xylopia aethiopica significantly affected the serum and testicular cholesterol $(\mathrm{P}<0.001)$ at a dose of
$100 \mathrm{mg} / \mathrm{kg}$ while the serum, testicular and epididymal proteins significantly increased $(\mathrm{P}<0.001)$ at the dose of $200 \mathrm{mg} / \mathrm{kg}$. Multiple correlation analysis showed that the secretion of testosterone was related to the testicular cholesterol $\left(\mathrm{r}^{2}=0.90\right)$ (table 3$)$.

Table 3: Effects of aqueous extract of Xylopia aethiopica on biochemical (total cholesterol and protein) parameters

\begin{tabular}{|c|c|c|c|c|}
\hline \multirow[t]{2}{*}{ Biochemical parameters } & \multicolumn{4}{|c|}{ Doses (mg/kg) } \\
\hline & Control & 100 & 200 & 300 \\
\hline Total serum protein (g/dl) & $5.52 \pm 0.82$ & $6.05 \pm 0.36$ & $8.68 \pm 0.14^{* * *}$ & $6.22 \pm 0.18$ \\
\hline Total testicular protein (g/dl) & $1.59 \pm 0.12$ & $1.67 \pm 0.31$ & $3.93 \pm 0.08^{* * *}$ & $1.71 \pm 0.19$ \\
\hline Total epididymal protein (g/dl) & $1.49 \pm 0.26$ & $1.70 \pm 0.10$ & $3054 \pm 0.06^{* * *}$ & $1.73 \pm 0.15$ \\
\hline Total serum cholesterol (mg/dl) & $69.14 \pm 1.97$ & $135.91 \pm 2.01^{* * *}$ & $75.05 \pm 7.2$ & $73.25 \pm 5.19$ \\
\hline Total testicular cholesterol (mg/dl) & $54.98 \pm 5.91$ & $104.91 \pm 0.96^{* * *}$ & $60.55 \pm 2.26$ & $58.51 \pm 3.81$ \\
\hline
\end{tabular}

Value are mean $\pm S E M ; n=6$; values are statistically significant at $\mathrm{P}<0.001$ level of significance. ${ }^{* * *}$-compared with control $\mathrm{P}<0.001$

\section{Effect of aqueous extract of Xylopia aethiopica on sex hormone} level

In this study, the highest testosterone level was observed at the dose of $100 \mathrm{mg} / \mathrm{kg}$ of Xylopia aethiopica $(\mathrm{P}<0.01)$. Multiple correlation analysis showed that testosterone level was related to the serum cholesterol ( $\left.\mathrm{r}^{2}=0.83\right)$ (fig. 2).

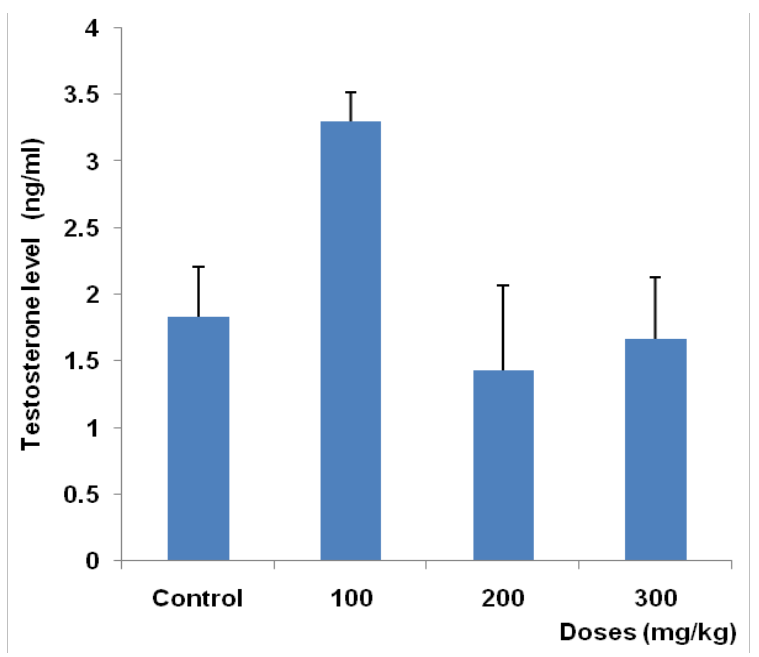

Fig. 2: Effect of aqueous extract of Xylopia aethiopica on testosterone level. Value are mean $\pm S E M ; n=6$; value is statistically significant at $P<0.01$ level of significance. ${ }^{* *}$ compared with control $P<0.01$

\section{DISCUSSION}

The use of plants in folk medicine still plays an important role in developing countries and particularity in Cameroon. Nowadays, the practical utilization of traditional medicines has received remarkable consideration and a large number of plants have been screened for their fertility enhancing properties [17]. In the present study, neither significant difference was observed among groups in body weight gain nor did weight of some accessory organs. However, it was noted at the dose of $100 \mathrm{mg} / \mathrm{kg}$, a significant increase $(p<0.01)$ of the relative weight of the prostate which is a body whose activity is linked to the secretion of androgen. This finding concerning the absence of weight gain is in line with the earlier report showing that aerial parts of this plant possess a hypolipidemic activity [18]. The increase of weight of prostate is similar to work reported by Güldeniz et al. 2009 [19]. This would suggest that the bark aqueous extract of Xylopia aethiopica would have androgenic properties. Indeed, it is known that androgens are steroids possessing anabolic activity at target tissues [20]. It has also been shown in rats that any increase in the testosterone level or any Androgen therapy induces secretory activity and elevated sexual organ weight [21]. It is why we observed an increase in testosterone levels at the same dose $(100 \mathrm{mg} / \mathrm{kg})$ in this work.

In the present investigation, the observed increase in daily sperm production to animals treated at a dose of $100 \mathrm{mg} / \mathrm{kg}$ might be due to an increase in the pattern of androgen secretion which increased at that dose and also to the presence of flavonoids in the extract. In fact, increased production of sperm cells in the seminiferous tubules is always associated with an increase in testosterone secretion that interacts with follicle stimulating hormone (FSH) during the process of spermatogenesis [22]. On the other hand, several lines have indicated that flavonoids possess reproductive and pharmacological 
properties [23-25]. Firstly, these flavonoids could directly act as antioxidants at the target cells and by this way contribute to the improvement of fertility [26]; secondly, they could maintain the synthesis of androgens by inhibiting $17 \beta$ estradiol aromatase, which is the enzyme involve for the conversion of testosterone to estrogen [27].

The mammalian testis is under the overall control of pituitary gonadotropins but the utilization of these signals to achieve normal testicular function involves complex local interactions between the Sertoli, germ and Leydig cells. These interactions serve to control the complex but orderly sequence of events that constitute the spermatogenic cycle. This process involves multiplication, differentiation and translocation of the germ cells. One of the factors involved in controlling the formation of sperm cells, is testosterone which is the result of the activity of Leydig cells [28]. Among the aqueous extract of Xylopia aethiopica treated animals, group treated at dose of $100 \mathrm{mg} / \mathrm{kg}$ produced a significant increase in testosterone level. This may be as a result of the ability of the aqueous extract of Xylopia aethiopica at the given doses, to stimulate the activity of Leydig and Sertoli cells. It is well established that both Leydig and Sertoli cells are required for testosterone synthesis in the mouse fetal testis [29]. Indeed, Leydig cells secrete testosterone and are able to synthesize cholesterol obtained by lipoproteins uptake relative to synthesis from acetate [30]. In the present study, there was a significant correlation $\left(\mathrm{r}^{2}=0.90\right)$ between the production of testosterone and testicular cholesterol at dose of $100 \mathrm{mg} / \mathrm{kg}$, showing in this case, the direct action of some secondary metabolites, mainly flavonoids which are present in the extract and that can modulate the synthesis of testosterone [31]. On the other hand, earlier reports demonstrated the important role of testicular proteins in sperm maturation [32]. The testicular androgen-binding protein (ABP) is synthesized in Sertoli cells as a response to FSH stimulation. Androgen binding protein (ABP) is transported with the testicular fluid into the caput epididymis, where it is partly taken up by the lining epithelial cells where it serves as an important store of androgenic hormones (mainly testosterone and dihydrotestosterone) that are necessary for initiation and maintenance of spermatogenesis [33].

The present work also showed that, at a dose of $200 \mathrm{mg} / \mathrm{kg}$, there was no significant ( $p 0.05$ ) decrease of daily sperm production as well as the decrease of testosterone at the same dose when compared to control. Nevertheless, at that dose, we noticed a remarkable increase ( $p<0.001$ ) of sperm count and transit in epididymis. The significant increase in sperm count and transit in this work was likely linked to the significant increase $(p<0.001)$ of the epididymal proteins observed at the same dose $(200 \mathrm{mg} / \mathrm{kg})$. It is why there was a high correlation $\left(\mathrm{r}^{2}=1\right)$ between the sperm transit and epididymal proteins. It has been already postulated that some proteins of testis and epididymis ensure the sperm maturation and transit. Indeed, epididymal channel participates in the maturation and the transit of sperm, or by secreting enzymatic proteins (glycohydrolases or glycosyl transferases) that are absorbed into the plasma membrane of the sperm during their stay in the luminal tube of epididymis [34]; either through the cleavage of testicular proteins (fertilin beta) pre-existing on the surface of the plasma membrane of the sperm [35]. These proteins are necessary and essential to ensure to male gametes their optimal fertilizing ability [36], although in the present work we observed a decline of sperm motility, one of a very important parameter involved for evaluating male fertility potential. It is then clear that the $200 \mathrm{mg} / \mathrm{kg}$ dose could influence the maturation of the spermatozoa in the male rats, which might also be a contributory factor to the increase of the overall sperm count of the epididymis.

\section{CONCLUSION}

In conclusion, these results indicate that treatment with the aqueous extract of Xylopia aethiopica could improve the fertility of male rats. Nevertheless, further investigations on animals with impaired reproductive capabilities are required in this study to better confirm traditional claims concerning the use of this plant on male infertility.

\section{ACKNOWLEDGEMENT}

The authors are grateful to the University facilities and are thankful to Pr. Theophile Dimo and Pr. Paul Moundipa University of Yaounde I for necessary help and guide.

\section{AUTHORS CONTRIBUTIONS}

\author{
BRICE LANDRY KOLOKO: Designed the work
}

CYPRIEN MAGLOIRE HAMBE: Data collection

HUBERT KENMOGNE and MARIE NGAHA NJILA: Analysis of data

DIEUDONNE MASSOMA LEMBE: Wrote the manuscript and contributed the materials/analysis tools/reagents

\section{CONFLICT OF INTERESTS}

Authors declare no conflict of interest

\section{REFERENCES}

1. Kashani HH, Malekzadeh SS, Hoshmand F. The effect of aqueous extract of salep prepared from root-tubers of Dactylorhiza maculate (Orchidaceae) on the testes and sexual hormones of immature male mice. J Med Plants Res 2012;6:4102-6.

2. Massoma LD, Koloko BL, Bend EF, Domkam J, Oundoum OPC, Ngaha NM, et al. Fertility enhancing effects of aqueous extract of Rauvolfia vomitoria on reproductive functions of male rats. J Exp Integr Med 2014;4:43-9.

3. Verma PK, Sharma A, Mathur A, Sharma P, Gupta RS, Joshi SC, et al. Effect of Sarcostemma acidum stem extract on spermatogenesis in male albino rats. Asian J Androl 2002; 4:43-7.

4. Sudhir AA, Rajendra BP, Prashant DG, Ms Vinita P, Deshbandhu $\mathrm{P}$, Haja S. Aphrodisiac activity of aqueuous extract of Glycyrrhiza glabra in male wistar rats. World J Pharm Res 2012;1:371-8.

5. Félicite N, Habiba K, Thierry H, Eric H, Leonard ST, Pierre M, et al. Composition of Xylopia aethiopica (Dunal) A. Rich essential oils from cameroon and identification of a minor diterpene: ent-13-epi manoyl oxide. Biotechnol Agron Soc Environ 2007;1:193-9.

6. Anvam ZPH. Extraction et analyse des huiles essentielles de trois especes de la famille des Annonacees du cameroun. Faculte Des Sci Yaounde Armand Collin Paris 1998;27:5è. 88.

7. Ekpo IA, Agbor RB, Osuagwu AN, Ekanem BE, Okpako EC, Urua IS. Phytochemical and comparative studies of the stem bark and root of Xylopia aethiopica (Dunal.) A Rich. World J Biol Res 2012;5:41-4.

8. Ekeanyanwu RC, Etienajirhevwe OF. Phytochemical analysis and in vitro anthelmintic potentials of Xylopia aethiopica (Dunal) a. rich (Annonacea) from Nigeria. Int J Biol Pharm Allied Sci 2012;1:322-30.

9. Guidelines for the appropriate use of herbal medicines. WHO Regional Office for Western Pacific, Manila; 1998. p. 65.

10. Gonzales GF, Gasco M, Cordova A, Chung A, Rubio J, Villegas L. Effect of Lepidium meyenii (Maca) on spermatogenesis in male rats acutely exposed to high altitude $(4340 \mathrm{~m})$. J Endocrinol 2004;180:87-95.

11. Takahashi 0, Oishi S. Testicular toxicity of dietarily or parenterally administered bisphenol A in rats and mice. Food Chem Toxicol 2003;41:1035-44.

12. Kubota K, Ohsako S, Kurosawa S, Takeda K, Qing W, Sakaue M, et al. Effects of Vinclozolin administration on sperm production and testosterone biosynthetic pathway in adult male rat. J Reprod Dev 2003;49:403-12.

13. Dalsenter PR, de Araujo SL, Assis HC, Andrade AJ, Dallegrave E. Pre and postnatal exposure to endosulfan in wistar rats. Hum Exp Toxicol 2003;22:171-5.

14. Gornall AG, Bardawill CJ, David MM. Determination of serum proteins by the means of biuret reactions. J Biol Chem 1949;177:751-66. 
15. Bradford MM. A rapid and sensitive method for the quantification microgram quantities of proteins utilising the principle of protein binding. Anal Biochem 1976;72:248-54.

16. Forbes JC. Dosage du cholesterol. J Lab Med 1930;16:520.

17. Mohan VR, Balamurugan K, Sakthidevi G. Fertility enhancement of Polycarpaea corymbosa (L.) Lam (Caryophyllaceae) whole plant on male albino rats. Asian J Pharm Clin Res 2013;6:151-5.

18. Amayaw Y, Owusu AE. Morphohistological studies of two plants species used in ethnomedicine. J Herbs Spices Med Plants 1998;5:60-85.

19. Güldeniz S, Sibel H, Durdane K, Aslı OT, Kadriye S. The effect of pollen on some reproductive parameters of male rats. Scientific paper Naucni Rad; 2009. p. 59-63.

20. Johnson MH, Everitt BJ. Essential reproduction. Third Edition. Oxford: Black Well scientific publications; 1988. p. 53.

21. Gonzales GF. Function of seminal vesicles and their role in male fertility. Asian J Androl 2001;3:251-8

22. Cheng CY. Molecular mechanisms in spermatogenesis. Adv Exp Med Biol 2008;636:1-289.

23. Joy KL, Kuttan R. Inhibition by Phyllanthus amarus of hepatocarcinogenesis induced by $\mathrm{N}$-Nitrosodiethylamine. J Bioch Nutr 1998;24:133-9.

24. Kassuya CA, Silerstre AA, Rehder V, Calixto JB. Anti allodynic and antioedematogeni properties of the lignan from Phyllanthus amarus in models of persistent inflammatory and neuropathic pain. Eur J Pharm 2003;478:145-53.

25. Adeneye AA, Benebo AS, Agbaje EO. Protective effect of the aqueous leaf and seed extract of Phyllanthus amarus on alcohol-induced hepatotoxity in rats. West Afr J Pharmacol Drug Res 2007;22:42-50.

26. Obianime AW, Uche FI. The phytochemical constituents and the effects of methanol extract of Phyllanthus amarus leaves (kidney stone plant) on the hormonal parameters of Male guinea pigs. J Appl Sci Environ Manage 2009;13:5-9.

27. Parandin R, Ghorbani R. Effects of alcoholic extract of Achilea mellefolium flowers on fertility parameters of male rats. Int J Pharm Tech Res 2010;2:2492-6.

28. Agrawal S, Chauhan S, Mathur R. Anti-fertility effects of embelin in male rats. Androl 1986;18:125-31.

29. Shima Y, Miyabayashi K, Haraguchi S, Arakawa T, Otake H, Baba $\mathrm{T}$, et al. Contribution of leydig and sertoli cells to testosterone production in mouse fetal testes. Mol Endocrinol 2013;27:63-73.

30. Kenneth L, Becker. Principles and practice of endocrinology and metabolism. Medical; 2001. p. 957.

31. Qin DN, She BR, She YC, Wang JH. Effects of flavonoids from semen cuscutae on the reproductive system in male rats. Asian J Androl 2000;2:99-102.

32. Sullivan R, Saez F, Girouard J, Frenette G. Role of exosomes in sperm maturation during the transit along the male reproductive tract. Blood Cells Mol Dis 2005;35:1-10.

33. Spaliviero JA, Jimenez M, Allan CM, Handelsman DJ. Luteinizing hormone receptor-mediated effects on initiation of spermatogenesis in gonadotropin-deficient (hpg) mice are replicated by testosterone. Biol Reprod 2004;70:32-8.

34. Tulsiani DR. Glycan-modifying enzymes in luminal fluid of the mammalian epididymis: an overview of their potential role in sperm maturation. Mol Cell Endocrinol 2006; 250:58-65.

35. Nishimura H, Cho C, Branciforte DR, Myles DG, Primakoff P. Analysis of loss adhesive function in sperm lacking cyritestin or fertilin beta. Dev Biol 2001;233:204-13.

36. Frenette G, Lessard C, Sullivan R. Polyol pathway along the bovine epididymis. Mol Reprod Dev 2004;69:448-56. 